\title{
Johann Natterer and the Amazonian languages
}

\author{
Johann Natterer e as línguas da Amazônia \\ Willem F.H. Adelaar \\ Hélène B. Brijnen ${ }^{1}$
}

\begin{abstract}
Johann Natterer (1787-1843) was a member of the Austrian scientific expedition that was sent to Brazil in 1817. As a zoologist, Natterer practised taxidermy in situ and provided the Austrian court with a large collection of stuffed animals and ethnographic objects. Less known is his dedication to the collection of linguistic data. After the expedition was called back in 1822, Natterer obtained permission to stay on. He remained in Brazil until 1835 and collected language materials (Sprachproben) of 72 indigenous languages. For many of the languages concerned, Natterer's hand-written data are either the first or the only records in existence. They are accompanied by ethnographic observations, indicating the original location of groups. In several cases, the speakers of language groups documented by Natterer have since then been removed from their original territories, if their languages were not brought to extinction. After a turbulent history, Natterer's original language data, which for a long time remained unnoticed, are now kept at the Library of the University of Basel in Switzerland, where they have also been digitalized. Their transcription and publication is being undertaken by the authors of the present article.
\end{abstract}

Keywords: Indian languages from South-America. Language samples from South-America. South-American ethnography. Indians in Amazonia. Johann Natterer.

\section{Resumo}

Johann Natterer (1787-1843) foi membro da expedição científica austríaca enviada para o Brasil em 1817. Como zoólogo, Natterer praticou a taxidermia in situ e forneceu à corte austríaca uma vasta coleção de animais empalhados e de objetos etnográficos. Menos conhecida e a sua dedicação a coletar dados linguísticos. Depois da expedição ter sido chamada de volta, em 1822, Natterer obteve a autorização para prolongar a sua estadia. Permaneceu no Brasil até 1835 e coletou amostras linguísticas (Sprachproben) de 72 línguas indígenas. Para muitas das línguas contidas nessa coleta, os dados manuscritos de Natterer representam os primeiros o inclusive os únicos registros existentes. Esses materiais estão acompanhados de observações etnográficas, com indicação do local de procedência dos grupos em questão. Com o passar do tempo, em muitos casos, os falantes

${ }^{1}$ Leiden University Center for Linguistics. 
dos grupos linguísticos documentados por Natterer foram forçados a abandonar as suas terras e as suas línguas com frequência foram extintas. Depois de uma história turbulenta, os dados linguísticos originais de Natterer, que por muito tempo tinham ficado perdidos, são conservadas atualmente na Biblioteca da Universidade de Basel, na Suíça, onde foram digitalizados. A transcrição e publicação está sendo realizada pelos autores do presente artigo.

Palavras-chave: Línguas indígenas da América do Sul. Amostras de línguas sul-americanas. Etnografia da América do Sul. Índios da Amazônia. Johann Natterer.

\section{Introduction ${ }^{2}$}

Johann Natterer (1787-1843) was a member of the scientific expedition which was sent to South America in 1817 by the Austrian emperor Franz I on the occasion of the wedding of his daughter Leopoldine to Dom Pedro I, emperor of Brazil. As a zoologist and a professional hunter, Natterer practiced taxidermy in situ and provided the Austrian court with a large collection of prepared animals and ethnographic artifacts. Less known, however, are Natterer's dedication to the collection of language data and his efforts to document the languages of the indigenous tribes which he met during his sojourn and travels in Amazonia. That Natterer recognized the importance of documenting the languages and disclosing the linguistic diversity of newly explored Amazonian territories was not surprising. For an enterprising explorer such as Natterer it was natural to adhere to the current of scientific curiosity that pervaded academic circles in western society in the early $19^{\text {th }}$ century and of which the documentation of newly discovered languages constituted a well-established part. In order to conduct his linguistic queries, Natterer could furthermore benefit from the example of the Hessian geologist and geographer Wilhelm Ludwig von Eschwege (17771855), who had established a questionnaire in order to collect word-lists of native languages in the eastern part of Brazil (Eschwege 1818 (I):165-171). In one of his letters (cf. Schmutzer 2011:92), Natterer explicitly states his intention to use Eschwege's questionnaire as a model for his own recollection of language data, referred to as Sprachproben ('language samples'). However, Natterer's exceptionality resides in the size of his documentation work, the systematic character of his recording efforts, and the difficult circumstances under which his word-lists would have been obtained. For many Amazonian languages documented by Natterer there had been no previous record. Consequently, for a substantial number of indigenous languages spoken in the Amazon today Natterer's language samples provide the earliest records. For some languages

\footnotetext{
${ }^{2}$ A slightly different version of this article has been published in a volume on Natterer's scientific contributions edited by Chr. Feest (Archiv 63-64, p. 162-183. Vienna: Archiv Weltmuseum Wien).
} 
that became extinct, Natterer's data provide the sole existing material or one of a limited number in case other records exist. Natterer provided his word-lists with extensive ethnographic notes, most of which have been published in Kann (1989).

\section{The trajectory of Natterer's language samples}

For a long time, Natterer's language data were thought to be irretrievably lost. It was assumed that they had fallen prey to the Hofburg fire which took place during the revolutionary troubles that besieged the Austrian capital in 1848 (cf. Nowotny 1949). However, annotations by Carl Friedrich Philipp von Martius (1867 (II):225 ff.) made it plausible to presume that this renowned explorer and geographer had had access to Natterer's language samples seven years after the 1848 fire, which leads to the conclusion that they were not yet considered missing at that time. Martius published five word-lists based on Natterer's work. They concern the languages Caripuná (Jaũn Avvo), Macushi, Paravilhana, Uirina and Yucuna. ${ }^{3}$ Martius also mentions Natterer's material in connection with the $19^{\text {th }}$ century Swiss scholar and diplomat Johann Jakob von Tschudi (1818-1889), who must have been in possession of the word-lists during the 1850 s and 1860 s.

Even during the time in which Natterer's records had disappeared from the public eye, their importance could still be inferred from the survival of a list of about 70 Amazonian languages that had been the object of his data collection. This list was published by K.A. Nowotny in the Viennese journal Archiv für Völkerkunde in 1949. To general surprise, the survival of Natterer's language samples was established in 1976, thanks to research conducted in the University Library of Basle by Ferdinand Anders, who was engaged in a biographical study of Tschudi (Anders 1984). He discovered that Natterer's language lists had been preserved among the documents of Tschudi's scientific bequest (Nachlass). Apparently, Tschudi had kept the language lists at his residence, where he had begun to decipher and transcribe Natterer's very personal handwriting. He must have abandoned the task after some time, as can be inferred from the fact that his transcription efforts did not extend beyond the first few languages in the collection.

Even today (2013), Natterer's language samples are not yet available in published form. They can be consulted in their original handwritten form or in a digitized version prepared by the University Library of Basle. ${ }^{4}$

\footnotetext{
${ }^{3}$ The Uirina and Yucuna lists included in Natterer's data are in a handwriting different from his own and may have been collected by someone else.

${ }^{4}$ The authors of this article are preparing a transcription of Natterer's Basle wordlists, which will be published after completion.
} 


\section{Languages documented by Natterer}

Overviews of the languages included in Natterer's samples can be found in Nowotny (1949) and in Kann (1989). The latter provides transcriptions of the ethnographical notes that accompany most of the word-lists. In the present section, we will try and group the documented languages according to their genetic affiliation, so as to give an idea of the diversity and uniqueness of the data collected by Natterer. The focus of Natterer's samples lies on languages spoken and located in Brazil. However, his lists include languages spoken in the neighboring countries Bolivia, Colombia, Guyana, Paraguay, Peru and Venezuela as well.

Languages of the Arawak family are particularly well represented among the languages documented by Natterer. Many of them are now extinct, as they occupied strategic river locations easily affected by European colonization. For some of these languages (e.g. Meppuri) there seem to be no other sources than Natterer's word-lists. Other languages, such as Manao (Manau), ${ }^{5}$ Passé and Jumana (Schumana) have disappeared long ago. An important cluster of Arawak languages is found in the basin of the Rio Negro, extending from Manaus to the Colombian, Venezuelan and Guyanese border areas. They include the languages Arauaqui (Aroaqui), Baniwa do Içana (Banniva), Baré (in two varieties: Arihini Baré and Ihini Baré), Caixana, Cariaü, Jumana, Mainatari, Manao, Meppuri, Passé, Tariana, Uirina, Vuainamboü (a language very close to Baniwa), Warekena (Uarequenna, located on the river Xié and extending into neighboring Venezuelan territory, cf. Aikhenvald 1999), Yabaána (Iabahani) and Yucuna (spoken in Colombia).

Of particular interest are two apparently extinct (or unidentified) languages situated in the area south of the Amazon river in the present-day state of Amazonas: Marawá (Marauiá) and Katukina do Juruá (Schuruá), the latter not to be confused with the non-Arawak language of the same name. Three languages are found in the savanna area that forms the border region between Brazil and Guyana: Atoraí (Aturai), Parahoana and Wapishana (Vapeschana). Southwestern Brazil and neighboring Bolivia are represented with the languages Guaná (Quiniquinao), Parecís and Saraveka.

The second group in number of languages represented in Natterer's data are the Tucanoan languages, in particular, the Eastern Tucanoan languages that are mostly located on both sides of the Brazilian-Colombian border. They include the languages Arapaçu, Coaihuana or Caiohana, Cubeo (Köbéu), Desana (Dessana), Macuna, Piratapuia and Tucano (Tocanna). For some of these languages a comparison with data from Tucanoan languages still spoken today will be necessary in order to determine their exact identity within that family.

\footnotetext{
${ }^{5}$ Denominations of languages and tribes used by Natterer that differ in spelling or form
} from modern usage are represented in italics. 
Arapaçu and Coaihuana may be close to present-day Tuyuca. Natterer's samples furthermore include a Western Tucanoan language, referred to as Paivita. Its location on the Napo river suggests proximity to Tucanoan languages in northeastern Peru and possibly Ecuador (Orejón, Siona, etc.).

Another language group that is particularly well represented in Natterer's data is the Macro-Jê stock. Only one Jê language is exemplified, namely, Kaingang (referred to as Cameh), but data for some of the other Macro-Jê branches are abundant. They include Bororo, recorded in several of its varieties, Chiquito (Tschikitos or Guasaroka spoken in Bolivia), Guató (Vuató) and Purí-Coroado, represented by two of its member languages, Coroado and Coropó. Nowotny (1949) mentions the existence of additional data on Purí (Purí-Coroado), but these could not be located among the Basle lists. They may have been lost, or a confusion with Coroado may have occurred.

The Tupian language stock is represented with several of its families, namely, Mawé, Mondé, Mundurucú (2 lists) and Tupi-Guaraní. Tupi-Guaraní is represented by the language Apiacá. The low representation of the Tupi-Guaraní languages in Natterer's samples is remarkable. It may reflect changes in the distribution of these languages that have occurred over the past two centuries. Nowotny (1949) mentions the existence of data on Tupinambá, which are no longer found among the Basle lists. If they existed at all (which seems likely considering Natterer's area of activity), they were probably lost.

Of special interest are two, almost identical Mondé languages. These are referred to by names that suggest other affiliations: Kabanaé (or Arara) and Matanau. The former two denominations have been associated with the Cariban languages (Loukotka 1968:221), the latter with an unclassified language (Matanawi). However, Natterer's samples do not leave much room for doubt as to the Mondé affiliation of the languages represented.

The Cariban family is represented by Caripuna, Macushi (Macuschi, 2 lists) and Paravilhana. All these language are located in the transitional area between Brazil and Guyana.

Only one Panoan language is found in Natterer's data, Caripuna (not to be confused with the Cariban language of the same name). According to Natterer, its speakers also used the self-denomination Jaũn Àvo. The low incidence of Panoan languages in Natterer's data may reflect a relatively recent expansion of these languages into Brazil from eastern Peru and northern Bolivia.

A number of smaller language families are furthermore represented in Natterer's samples. The Macu languages were recorded in two varieties, presumably corresponding to modern Hup and Nadëb. The languages Ticuna and Yurí, which are now considered related (Orphão de Carvalho 2009; Seifart, pers. comm. 2013), are both represented in the data. There are two lists exemplifying the Mura language of the Mura-Pirahã family. The Boran family 
(mainly located in Colombia and Peru) is represented with a list of Miranha. The Arawá family is represented with a list of the Paumarí language (referred to by Natterer as Poropurús or Pamoari). The Katukina family is represented by two lists referred to as Katukina (one of them is too short to permit a proper identification and may actually represent a Tupi-Guaraní language) and one list of the presumably extinct Katawixí language (see below). A language referred to by Natterer as Urequena, which he locates on the river Iça (or Putumayo), appears to be closely related (if not identical) to the Andoke language of southeastern Colombia. ${ }^{6}$ So far, the Andoke language has been considered a genealogical isolate (Landaburu 1979).

The Guaicuruan languages, located in the Gran Chaco, southern Mato Grosso and the border area with Paraguay are well represented by several lists sampling the extinct Guaicuru language, which gave its name to the family. Another language, Guatschié, may be Guaicuruan, but the sample list is too short to permit a positive identification by now.

In addition to Guatschié, a number of other languages still defy identification, requiring further research. The Cabixi language (from Mato Grosso), which may have been tonal judging from its structure and the diacritics added by Natterer, could not be assigned to any of the known existing language families. It has been suggested to belong to the Nambikwaran language family (Borella, pers. comm.; Jolkesky, pers. comm). Other languages for which no affiliation or identification could be found so far are Cararí, from the river Mucuim in the south of the state of Amazonas, and Unainuman (possibly Vuainuman ), from a tributary of the river Iça (which is called the Putumayo in its middle and upper course). The Unainuman list is rather incomplete, but for Cararí an eventual identification may be feasible. It shows characteristics of an Arawak language, although it seems to lack the usual possessive prefixes.

Of the Schamucoco language (presumably Chamacoco of the Zamucoan family) only two words were recorded ${ }^{7}$, and for the language Jubiri (Schubiri), Natterer's materials only provide an empty list.

\section{Linguistic relevance of Natterer's data}

For several Amazonian languages, Natterer's word-lists constitute the earliest known record. However, their value and interpretability have increased considerably due to a substantial increase in the volume of field research conducted on these languages since the 1990s. It has now become easier to interpret data that have not been the object of morphological analysis previously. The differences between Natterer's data and those that have been collected in

${ }^{6}$ This identification of Urequena as an Andoke(an) language is due to Marcelo Jolkesky.

${ }^{7}$ The Chamacoco identity of these two forms has been confirmed by Luca Ciucci (pers. comm.). 
recent decades are significant, because they give an indication of the amount of change that the languages recorded have undergone during the past two centuries. Natterer's approach to the Amazonian languages can be assessed by comparing his language materials with more recently recorded data, and such an assessment is in turn helpful for the interpretation of Natterer's data on extinct languages for which no modern records are available.

As was usual in the $19^{\text {th }}$ and early $20^{\text {th }}$ century, most of the language samples recorded by Natterer consist of nouns, supplemented with a few short phrases or expressions. The selection of words and phrases was made on the basis of Eschwege's model, although Natterer did not hesitate to include more items when relevant. Verb forms were also recorded, but not frequently. In most Amazonian languages, both nouns and verbs are subject to relatively complex morphological processes, involving the use of prefixes and suffixes alike. Nouns are regularly preceded by prefixes indicating the possessor or figurative owner of the entity to which the noun refers. Some categories of nouns, in particular, the names for body parts and kinship relations, rarely occur without such prefixes or not at all. The logical result is that Natterer's language data contain many cases of nominal roots preceded by possessive affixes, but fortunately Natterer showed himself consistent in always recording the first person singular form of such possessed nouns. Consequently, as a reader one has to be familiar with some of the basic structures and forms of the exemplified languages, but at the same time the omnipresent first person singular marker is helpful for establishing the linguistic affiliation of the languages recorded. For instance, in the lists concerning the Bororo language (belonging to the Macro-Jê linguistic stock), many entries begin with the element $i$-, which is characteristic of the first person singular marker in that language (e.g. $i$ ugà /i-oga/ '[my] father', ikelà /ik-era/ '[my] hand'; cf. Crowell 1979: 207, Szerwinsk Camargos 2010: 79), whereas languages of Arawak affiliation are easily recognized by the presence of the $n u$ - or no- prefix, which has a similar function in most languages of that family, for instance, Tariana nohüda /nu-hwida/ '[my] head', noédoa /nu-wédo/ '[my] younger sister' (Aikhenvald ms. 2007); Baniwa do Içana numheré / nu-hméree-ri/ ' [my] younger brother', nocàpi /nu-kaapi/ '[my] hand' (cf. Taylor 1991:23, 33).

On the level of the orthographic notation, Natterer did not benefit from a rich tradition in phonetic sciences, as present-day linguists do. In order to find a way to render the exotic speech sounds with which he was doubtlessly confronted he had to improvise. In the Bororo language samples, which were among the first to be elaborated by Natterer, he made ample use of diacritic signs, most of which are difficult to interpret today. A detailed study of the Bororo samples, in combination with an in-depth phonetic investigation of the language as it is spoken today, may eventually lead to a better understanding of the value of the diacritic signs. In some cases, the meaning of a diacritic is obvious, also 
because Natterer adds a comment to such effect. For instance, in the Bororo word itonarageté '[my] daughter', recorded in Natterer's lists, the acute accent of the symbol é serves to indicate that the vowel represented is not a front vowel [e], but rather a central vowel [i] (stummes e). It obviously contains the modern Bororo root /onaragedi/ 'child' (cf. Crowell 1979:169). In other cases, however, the same diacritic is used to represent a sound which is probably a mid front vowel [e], as in ikuisché 'star', modern Bororo /kuieje/ [kujedZe] 'star' (cf. Bezerra Nonato 2008:233). Note that in the Baniwa examples given above, the symbol é does not refer to a central vowel either (Baniwa has no central vowel). The motivation behind these different uses of é is not clear.

The preciseness of Natterer's phonetic observations can further be derived from the meaningfulness of the hiatus in his notations. Mostly, the symbols in his handwriting are connected, as can be expected in handwritten material meant for personal use, or contain elements suggesting that such a connection was intended. If there is no question of connected writing and the symbols are separated by a space, however modest, an interruption of speech or glottal stop is apparently intended. This can be observed in the language samples of the Katawixi language, recorded on the Tapauvá river, a tributary of the Purús, where the word for 'sand' is recorded as tiki $i$ 'sand' and that for 'axe' as to $i$ (Adelaar 2007:162). These words are represented as tikihi and toñhi, respectively, in the only other substantial documentation of the (presumably extinct) Katawixi language, recorded by the missionary Constant Tastevin around $1920 .{ }^{8}$ It seems likely that Natterer used the hiatus for the same purpose as Tastevin, who had a French background, the symbol $h .^{9}$ Predictably, a hiatus is also found in Natterer's transcription of the Bororo term for 'father' ( $i$ ugà, see above). Another example of this practice is found in Paumarí só oló 'basket', which corresponds to modern Paumari /so?oro/(Chapman and Derbyshire 1991:204).

\section{Sample of Natterer's wordlists: Baré Arihini}

As an example of Natterer's language samples, or Baseler Wortlisten, we include a transcription of his records on Baré Arihini, one of two varieties of the Baré language formerly spoken in the Upper Rio Negro region in the presentday state of Amazonas in Brazil and in adjacent Venezuelan territory. The Baré language belongs to the Arawak language family. Several sources mention the existence of two subgroups: Arihini ("the ones from here") in the Upper Rio Negro region and Ihini ("the ones from there") on the Middle Rio Negro (cf. Aikhenvald 1995). Natterer provides separate wordlists for Baré Arihini and

\footnotetext{
${ }^{8}$ Tastevin's records are kept in the archives of the Congregation of the Holy Spirit in Chevilly-la-Rue near Paris.

${ }^{9}$ Of course, it is also possible that the correspondence between $h$ and hiatus represents dialectal variation.
} 
Baré Ihini. On July $23^{\text {th }}, 1831$, he recorded data of Baré Arihini in the locality of Marabitana from a mamaluca (mixed-blooded) girl, who lived with her aunt in the village of Boa Vista.

In the following chart, German and occasionally Portuguese or local indigenous terms are given in Natterer's orthography. These are matched by their translation in Baré Arihini, as recorded in Natterer's word-list. Explanations are provided by the authors in footnotes. Scientific denominations given for plants and animals are mostly tentative.

Rio Vaupé 23 July 831

Sprachproben der Indier Baré. Bewohner von Marabitanas vom Stamm Arihini/Ali hini

\begin{tabular}{|l|l|}
\hline Quaksalber & $\begin{array}{l}\text { Malihidau } \\
\text { Kathi kaleni }\end{array}$ \\
\hline Gott & bassaboni uàli \\
\hline Teufel & ijèhii \\
\hline Vater & bába \\
\hline mein Vater & imbába \\
\hline Mutter & méme \\
\hline meine Mutter & im meme \\
\hline Sohn & nodit halé \\
\hline Tochter & nhissó \\
\hline Weib & inhadschaté \\
\hline Mann & hèinalí heìnali \\
\hline Junger Mann & hantitschàle \\
\hline Alter & miàli \\
\hline Grosvater & untéte ntéte \\
\hline Bruder & noañhañ \\
\hline Schwester & noàla \\
\hline Kind & kiapètei etwas größer hantí nohopé \\
\hline Kopf & nodòssia \\
\hline Hand & nokhábi \\
\hline Finger & nokhàbi hantibé \\
\hline Nägl & nhàba \\
\hline Fleisch & nodìti \\
\hline & \\
\hline
\end{tabular}




\begin{tabular}{|l|l|}
\hline Bein & nàbi \\
\hline Blut & hi i \\
\hline Milch & tenìahañ \\
\hline Weiberbrust & nodìni \\
\hline sterben & adani káni \\
\hline ich sterb. & nodani káni \\
\hline mein Bruder ist gestorben & noãhañ hadanikani \\
\hline
\end{tabular}

\begin{tabular}{|l|l|}
\hline Sonne & kamòhuñ \\
\hline Mond & khii zwey i \\
\hline Sterne & $\begin{array}{l}\text { kambé bukóli - Siebengestirn } \\
\text { anderes Gestirn Kassóhiàle ist d. } \\
\text { Orion }\end{array}$ \\
\hline Tag & hia hàni \\
\hline Nacht & tà ìna \\
\hline Donner & ennò \\
\hline Regen & hìia zw i. ${ }^{10}$ \\
\hline Blitz & oadà oadalí \\
\hline Wind & hau ìssi \\
\hline Berg & szeàba - sseàba \\
\hline Sand & kadiehò kadiéheơ \\
\hline Wasser & ùni \\
\hline Feuer & kamèni \\
\hline Fluß & itháli \\
\hline Rionegro & ùni da-inì \\
\hline See & kalìehábucù \\
\hline Bach & uàbo \\
\hline Cachoeira & Ticoàhalì \\
\hline Branntwein & Jialáki \\
\hline & \\
\hline & \\
\hline
\end{tabular}

\begin{tabular}{|l|l|}
\hline Stein & Tìba \\
\hline Holz & hitèki hitiki \\
\hline Wald & tau mà calucú \\
\hline
\end{tabular}

${ }^{10}$ zw i. (zwey i): two 'i'. 


\begin{tabular}{|l|l|}
\hline Baum & àda \\
\hline Gras & hibéni \\
\hline Fisch & ubáti \\
\hline Piraüba $^{11}$ & mhucòle \\
\hline Sorobim $^{12}$ & kolí \\
\hline Pirarara $^{13}$ & maphà \\
\hline Varane $^{14}$ & daàli \\
\hline Mandu $^{14}$ & kidihilì \\
\hline Acara $^{15}$ & hajù \\
\hline Delfin & hàmàna \\
\hline
\end{tabular}

\begin{tabular}{|l|l|}
\hline Cabeçudo $^{16}$ & Tibúli \\
\hline Tracaja $^{17}$ & thi pìru \\
\hline Jacaré $^{18}$ & hàdoli \\
\hline Jabuti $^{19}$ & kolìman \\
\hline Jacaré rana $^{20}$ & oạu iàli \\
\hline Tatu $^{21}$ grande $^{2}$ & (haianna) - ha iànna \\
\hline peq. & ha iuedàli \\
\hline
\end{tabular}

\begin{tabular}{|l|l|}
\hline Anta $^{22}$ & Teèma \\
\hline Taitetu $^{23}$ & à lua \\
\hline
\end{tabular}

\footnotetext{
${ }^{11}$ piraíba: a freshwater fish (Bagrus reticulatus).

${ }^{12}$ surubim: a catfish (Pseudoplatystoma sp.).

${ }^{13}$ pirarara: red-tail catfish (Phractocephalus hemioliopterus).

${ }^{14}$ mandu: an Amazonian fish sp.

${ }^{15}$ acará: name of several cichlid fish.

${ }^{16}$ cabeçudo: a freshwater fish (Pimelodus ornatus).

${ }^{17}$ tracajá: a species of river turtle (Podocnemis unifilis).

18 jacaré: caiman.

19 jabutí: land turtle.

${ }^{20}$ jacaré rana: fake caiman.

${ }^{21}$ tatu: armadillo.

22 anta: tapir.

${ }^{23}$ taitetú: collared peccary.
} 


\begin{tabular}{|c|c|}
\hline Hirsch & malàhai \\
\hline Hund & tschìino \\
\hline Unze $^{24}$ geflekt & koàti \\
\hline roth & kiabìssi \\
\hline Hahn & calácca \\
\hline Taube & hotókóli \\
\hline Urubu $^{25}$ & ekhòi \\
\hline urub. branco & baàli \\
\hline Gaviaõ real & kòkòi ko-koò i \\
\hline Arara roth ${ }^{26}$ & kaù éhi \\
\hline - gelbblau & anàùli \\
\hline Papagaio & cuijan \\
\hline Mutum $^{27}$ vermelho & Tibaióli \\
\hline $\mathrm{Nambu}^{28}$ & màmi \\
\hline Urù mutum $^{29}$ & itschìri \\
\hline Pato & uruma \\
\hline Mareca $^{30}$ & vanàna \\
\hline Jacaimim $^{31}$ & Ijàbi \\
\hline Juruti $^{32}$ & Vanàleo \\
\hline Mut. do Cu branco ${ }^{33}$ & Du mùcu \\
\hline
\end{tabular}

\begin{tabular}{|l|l|}
\hline Bohnen & comàna - stamt von $\mathrm{d}$ lingua geral \\
\hline Mays & meannassé \\
\hline
\end{tabular}

\footnotetext{
${ }^{24}$ unze: jaguar (Port. onça).

${ }^{25}$ urubu: vulture.

${ }^{26}$ arara: macaw.

${ }^{27}$ mutum: curassow.

${ }^{28}$ nambu: tinamou (partridge).

${ }^{29}$ uru-mutum: nocturnal curassow (Nothocrax urumutum).

${ }^{30}$ mareca: widgeon (a type of duck).

${ }^{31}$ jacamim: trumpeter (Psophia sp.).

${ }^{32}$ juruti: dove (Leptotila sp.).

${ }^{33}$ mutum do cu branco: a curassow (Crax alector).
} 


\begin{tabular}{|l|l|}
\hline Reis & au vàti lingua geral \\
\hline Mandioka $^{34}$ & kanití \\
\hline maniva $^{35}$ & kaniketí \\
\hline Pataten & Càhau \\
\hline Carà $^{36}$ & hèdiu \\
\hline Banane & banañ la \\
\hline
\end{tabular}

\begin{tabular}{|c|c|}
\hline Wassermelone & vuarassié - lingua geral \\
\hline Guaranà $^{37}$ & kubáno \\
\hline Farinha & Matschùca \\
\hline $\mathrm{Beju}^{38}$ & ko òssì in Fladen gedörte Farinha \\
\hline Tipioca $^{39}$ & meneàhabé \\
\hline Ralo para ralar mandioca & daijàma - \\
\hline Tipitit $^{40}$ & Szàlama - \\
\hline Sieb & jubìsssi \\
\hline Salsa parilha & Sarà̀ssa \\
\hline Ofen & Budàli \\
\hline Ananas & mau hàu i \\
\hline Jamarù $^{41}$ - Kabasse & thalúti \\
\hline Cuia $^{42}$ andr Kabasse & Gaiàle \\
\hline Komm her & tau wà̀ti \\
\hline Geh weg & pihi uàna \\
\hline
\end{tabular}

\footnotetext{
${ }^{34}$ mandioca: cassava (Manihot esculenta).

${ }^{35}$ maniva: cassava (Manihot utilissima).

${ }^{36}$ cará: yam.

${ }^{37}$ guaraná: the guaraná plant, Paullinia cupana (sorbilis).

${ }^{38}$ beiju: tapioca cake.

${ }^{39}$ tipioca $=$ tapioca.

${ }^{40}$ tipiti: cassava press.

${ }^{41}$ jamarú: a gourd (Cucurbita sp.).

42 cuia: bottle gourd (Lagenaria sp.).
} 


\begin{tabular}{|l|l|}
\hline geschwind & kamañ hàni (auch kàte) \\
\hline Langsam & madànịca \\
\hline Baumwurzl & (bithúda) addàdòli \\
\hline Frucht & adà pucù \\
\hline Ey & tenìcu \\
\hline Feder & thà abàte danàbáte \\
\hline Tabak & aàli \\
\hline Cigarro & dasselbe \\
\hline Tabakspfeife & cathimau - lingua geral \\
\hline Ich will rauchen & nop huìjucaia aali \\
\hline Bogen & Szé oèpi \\
\hline Pfeil & dabí dàhañ \\
\hline Blasrohr & ui dába \\
\hline kl. Pfeil & ui nañ hañ \\
\hline Pfeilgift & mau hacòli \\
\hline Patrone & thaù vàna \\
\hline mit Pfeil schießen & assé bidáni \\
\hline
\end{tabular}

\begin{tabular}{|c|c|}
\hline Spieß & Mulùccu \\
\hline Keule & kuidalù \\
\hline beißen & nokhalukáni \\
\hline der Hund hat mich gebissen & àli tschino akhalukanòni \\
\hline dies taugt nicht & (a ssà mapau dies ist sehr häßlich-) \\
\hline Ich bin satt & kadulèna nòni bakàna kìtę \\
\hline dies taugt nicht & ali heni idoalikke \\
\hline wo gehst du hin & auvatạte bihi oacà \\
\hline wo kommst du her & auèhéte $\quad$ hadìo tauàhàça bíni \\
\hline Es ist gut & mañhañ pàa \\
\hline Nein & hènna \\
\hline $\mathrm{Ja}$ & eñ heñ \\
\hline Bist du verheurathet & kaniodáli bini \\
\hline wenn man ein Weib fragt & kami dàli bini \\
\hline
\end{tabular}




\begin{tabular}{|l|l|}
\hline heute & voà khethèi \\
\hline gestern & jau akoheñ \\
\hline morgen & p.hatèba \\
\hline übermorgen & jabu còla \\
\hline Axt & e ep hí - das p und h hört man \\
\hline Messer & di teñheñ \\
\hline Schlafnetz & mhiñ \\
\hline Topf & iolòtí \\
\hline Wassertopf & dia va kehí \\
\hline Blashorn & pulé hé i \\
\hline Feuer machen & nihioà kamenī \\
\hline Haus & ì̀ssa - \\
\hline Kanot & p hàni - das $p$ und h hört man \\
\hline
\end{tabular}

\begin{tabular}{|l|l|}
\hline weiß & balinì \\
\hline schwarz & da inì \\
\hline roth & ki enì \\
\hline blau & bohòleni \\
\hline grün & koliní \\
\hline gelb & uitonì \\
\hline Essen & nonikani noiaha kú \\
\hline Ich will essen & nonikaia noiahakú \\
\hline trinken & noòdia \\
\hline eins & Pacunà kalí \\
\hline zwey & pikunamá \\
\hline drey & kölì bolenamà \\
\hline vier & kassàli amboléna \\
\hline fünf & vakà bineká \\
\hline viel & Halassì kạlę \\
\hline wenig & behentí \\
\hline kalt & hamenaù oakalí \\
\hline warm & dakhani \\
\hline
\end{tabular}




\begin{tabular}{|l|l|}
\hline Auge & noití \\
\hline Nase & notèi \\
\hline Ohr & nodàtenni \\
\hline Mund & nonoma \\
\hline Stirne & nodau ití \\
\hline Haare & nithà \\
\hline Zähne & nahài \\
\hline Zunge & nò neni \\
\hline Bauch & nodola \\
\hline Schenkl & nossò i \\
\hline Wade & nòcadi \\
\hline
\end{tabular}

\begin{tabular}{|l|l|}
\hline Fuß & nìissi \\
\hline Mänlich. Glied & jàla hài \\
\hline testikl & nocaù vauti \\
\hline Wbl Schaam & denjá hài \\
\hline Clitoris & noaiolé héssi \\
\hline foder ${ }^{43}$ & hanna bani \\
\hline Portugiese & Ialanoi \\
\hline Baniva & Baniva \\
\hline ich bin Baré & nòni Bâle \\
\hline Uerequenna & Ueléquennà \\
\hline Vaupé & Boaupé \\
\hline Rio Vaupé & $\begin{array}{l}\text { Boaupé thále } \\
\text { dieser Fluß heißt auch - Ucaiarì̀ }\end{array}$ \\
\hline I.hini & verschied. dialekt \\
\hline Schwein & Habià \\
\hline Cutia ${ }^{44}$ & uaiòlo \\
\hline Cutivaia ${ }^{45}$ & athìli \\
\hline
\end{tabular}

\footnotetext{
${ }^{43}$ Port. 'to copulate'.

${ }^{44}$ cutia: agouti.

${ }^{45}$ cutivaia: a rodent similar to the agouti or the capybara.
} 


\begin{tabular}{|l|l|}
\hline Sauiàa $^{46}$ & Mothòlio \\
\hline Pacca $^{47}$ & liàba \\
\hline Morcego $^{48}$ & bià hau \\
\hline Ouriço $^{49}$ & Hy uà \\
\hline Macaco prego $^{50}$ & Aù uami \\
\hline- caia rara $^{51}$ & aù uadàli \\
\hline- Vacary $^{52}$ & cacà hau \\
\hline- Guariba $^{53}$ & alàvàta \\
\hline$-{\text { iià }- \text { Nachtaffe }^{54}}^{5}$ & dohulocòli \\
\hline- vaiapossás $^{55}$ & maca vacau \\
\hline- Coata $^{56}$ & Aàlu \\
\hline Preguiça real $^{57}$ & Oalúti \\
\hline$-\quad$ peq- $^{5053550550}$ & o mesmo \\
\hline
\end{tabular}

$\mathrm{n}^{4647484950515253545556575859}$

\begin{tabular}{|c|c|}
\hline Tamandua $^{58}$ & haà u \\
\hline - pequ. & obìu \\
\hline Capibara & khö.iu \\
\hline Schupará ${ }^{59}$ & manö-ui \\
\hline
\end{tabular}

${ }^{46}$ saujá: 'rato-do-mato' (a spring rat).

${ }^{47}$ paca: Cuniculus paca (a rodent).

${ }^{48}$ morcego: bat.

${ }^{49}$ ouriço: hedgehog.

${ }^{50}$ macaco prego: capuchin monkey (Sapajus sp., Cebus sp.).

${ }^{51}$ macaco caiarara: a species of capuchin monkey.

${ }^{52}$ uacari: uacari monkey (Cacajao sp.). Note that the scientific denomination is based on the Baré word.

${ }^{53}$ guariba: howler monkey (Alouatta sp.). Note that the scientific denomination is based on the Baré word.

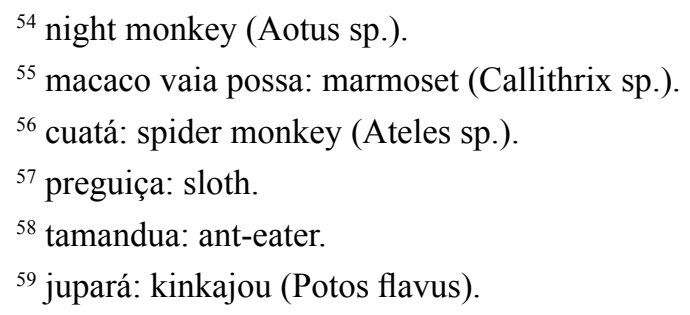




\begin{tabular}{|c|c|}
\hline Lontra $^{60}$ & Iné ui \\
\hline - pequena & vacùiàli \\
\hline Irará $^{61}$ & Guànaca \\
\hline Micura $^{62}$ & Vualissi \\
\hline - pequen. & p.huacáli \\
\hline Cutipurù $^{63}$ & Dsha bùi áli Dshà buiále \\
\hline Coati & Coanaoè \\
\hline Meriti $^{64}$ & Issé ui \\
\hline Tucum $^{65}$ & Vuai tìti \\
\hline Vacaba $^{66}$ & Bubè i \\
\hline \multicolumn{2}{|l|}{ Innaschà $^{67}$} \\
\hline $\begin{array}{l}\text { Art Palme, dessen Stamm anfangs kriecht } \\
\text { dann aufwärts geht - bey Faria im } \\
\text { Madeirafluß }\end{array}$ & Cai jau hé \\
\hline Panacù $^{68}$ & Imàssy \\
\hline Vatorá $^{69}$ & Thòbu - Korb zu Mandiok tragen \\
\hline Balaio & A pàma \\
\hline Sieb & Jubissi \\
\hline
\end{tabular}

diese Worte sind von einer Mamaluca / das ist Tochter eines Weißen mit einer Indierin - ihre Mutter war Baré, doch starb sie frühzeitig, und wurde daher von ihrer Grosmutter erzogen, eine wahre Baré das Mädchen hieß Ignez, und wohnt in Boa vista 1 Tagreise unterhalb Marabitanas, bey ihrer Tante Innocencia.

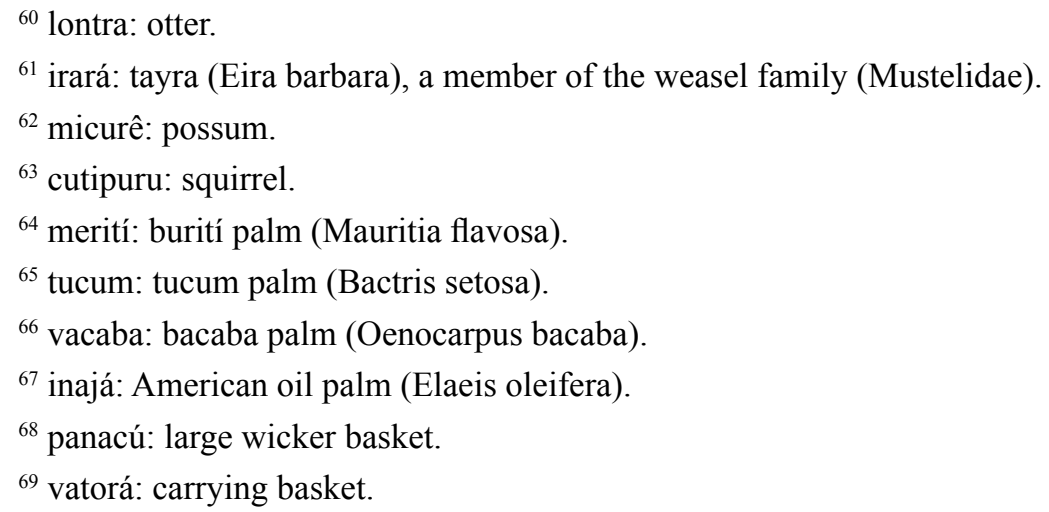




\section{References}

Adelaar, Willem F.H. 2007. Ensayo de clasificación del katawixi dentro del conjunto Harakmbut-Katukina. In: Andrés Romero-Figueroa, Ana Fernández Garay and Ángel Corbera Mori (eds.). Lenguas indígenas de América del Sur: Estudios descriptivo-tipológicos y sus contribuciones para la linguistica teórica, p. 159-169. Caracas: Universidad Católica Andrés Bello.

Aikhenvald, Alexandra Y. 1995. Bare. München, Newcastle: Lincom Europa. 1831.

(ms. 2007) Comments on the Tariana wordlist, collected by Johann Natterer,

Anders, Ferdinand. 1984. Johann Jakob von Tschudi: Forscher, Reisender, Diplomat. Schaffhausen: Museum zu Allerheiligen.

Bezerra Nonato, Rafael. 2008. Ainore Boe egore: um estudo descritivo da língua bororo e conseqüências para a teoria de caso e concordância. MA thesis IEL. Campinas SP: UNICAMP.

Chapman, Shirley \& Derbyshire, Desmond C. 1991. Paumarí. In: Desmond C. Derbyshire and Geoffrey K. Pullum (eds.). Handbook of Amazonian Languages, Volume 3, p. 161-351. Berlin: Mouton de Gruyter.

Crowell, Thomas H. (1979). A Grammar of Bororo. Ph.D. dissertation Cornell University. Ithaca - New York.

Eschwege, Wilhelm Ludwig von. 1818. Journal von Brasilien oder vermischte Nachrichten aus Brasilien, auf wissenschaftlichen Reisen gesammelt. 2 volumes. Weimar: im Verlage des Gr.H.G. pr. Landes-Industrie-Comptoirs.

Kann, Peter. 1989. Die ethnographischen Aufzeichnungen in den wiederentdeckten Wortlisten von Johann Natterer, während seiner Brasilienreise zwischen 1817-1835. Archiv für Völkerkunde 43, p. 101-146. Vienna.

Landaburu, Jon.1979. La langue des Andoke, Amazonie colombienne. Paris: Centre National de la Recherche Scientifique.

Loukotka, Čestmír. 1968. Classification of South American Indian Languages, ed. Johannes Wilbert. Los Angeles: University of California (UCLA), Latin American Center.

Martius, Carl Philipp Friedrich von. 1867. Beiträge zur Ethnographie und Sprachenkunde Amerikas, zumal Brasiliens. 2 volumes. Leipzig: F. Fleischer.

Nowotny, Karl Anton. 1949. Aufzeichnungen Johann Natterers über die Aufenthaltsorte brasilianischer Stämme in den Jahren 1817 bis 1835. Archiv für Völkerkunde 4, p.160-164.

Orphão de Carvalho, Fernando. 2009. On the genetic kinship of the languages Tikúna and Yurí. Revista Brasileira de Lingüística Antropológica 1,2, p. 247-268. Brasília.

Schmutzer, Kurt. 2011. 07. Der Liebe zur Naturgeschichte halber, Johann Natterers Reisen in Brasilien 1817-1836. 5. Ph.D. dissertation, Universität Wien. Vienna: Verlag der Österreichischen Akademie der Wissenschaften. 
Seifart, Frank, \& Juan Alvaro Echeverri. 2014. Evidence for the Identification of Carabayo. the Language of an Uncontacted people of the Colombian Amazon, as belonging to the Tikuna-Yurí Lingustic Family. PLoS ONE 9, 4: e94814

Szerwinsk Camargos, Lidiane. 2010. Relações gramaticais, aspecto, modo e modalidade em Boróro. MA thesis Universidade de Brasília: Instituto de Letras: Departamento de Lingüística, Português e Línguas Clássicas: Programa de Pós-graduação em Lingüística. Brasília.

Taylor, Gerald. 1991. Introdução à língua bániwa do Içana. Campinas SP: Editora da Universidade Estadual de Campinas (UNICAMP).

Data recebimento: 03/11/2014.

Data aceite: $20 / 11 / 2014$. 